\title{
Elynn Gorris. "The Harbour(s) of Nagitu: Mesopotamian Mooring Places, Elamite Garrisons and Aramean Settlements"
}

Yasmina Wicks

\section{(2) OpenEdition Journals}

\section{Electronic version}

URL: https://journals.openedition.org/abstractairanica/52273

DOI: 10.4000/abstractairanica.52273

ISSN: 1961-960X

Publisher:

CNRS (UMR 7528 Mondes iraniens et indiens), Éditions de l'IFRI

\section{Electronic reference}

Yasmina Wicks, "Elynn Gorris. "The Harbour(s) of Nagitu: Mesopotamian Mooring Places, Elamite Garrisons and Aramean Settlements"', Abstracta Iranica [Online], Volume 42-43 | 2021, document 4, Online since 15 April 2021, connection on 17 December 2022. URL: http://journals.openedition.org/ abstractairanica/52273 ; DOI: https://doi.org/10.4000/abstractairanica.52273

This text was automatically generated on 17 December 2022.

All rights reserved 
Elynn Gorris. "The Harbour(s) of Nagitu: Mesopotamian Mooring Places, Elamite Garrisons and Aramean Settlements"

Yasmina Wicks 


\section{REFERENCES}

Elynn Gorris. “The Harbour(s) of Nagitu: Mesopotamian Mooring Places, Elamite Garrisons and Aramean Settlements", Iranica Antiqua 54, 2019, p. 59-82, DOI: 10.2143/IA. 54.0.3287446

1 Noting the poorly known historical geography of the Elamite coastal region of the Persian Gulf during the first half of the first millennium BCE, the author proceeds to contribute new knowledge on the topic by investigating the toponym(s) Nagitu, an Elamite coastal settlement that appears quite frequently in Neo-Assyrian sources with various postpositions: Nagitu-raqqi “island-in-the-marshes", Nagitu-di'bina "coastal town-of-rocks", or Nagitu-of-Elam (ša KUR.ELAM.MA.KI). The various Nagitu attestations are collated and then their etymologies and geographical indications are examined to help determine their locations. The findings are then compared with descriptions of Classical authors and early Arab geographers to further flesh out a picture of the historical geography of the Nagitu triad.

2 It is concluded that Nagitu-raqqi and Nagitu-di'bina were located in Elamite Susiana. But docking difficulties in the Susiana littoral meant that the Nagitu harbour must have been located inland at the mouth of the Karun, giving ships access to the waterways of the Elamite hinterland. Thus, Nagitu can be considered an Elamite harbour town on the Susiana coastline offering an Elamite mooring place on the Elam-Sealand maritime transport route.

\section{AUTHORS}

\section{YASMINA WICKS}

Department of Archaeology, University of Sydney 